\title{
ELABORASI PESAN HOAX DI GRUP FACEBOOK INFO WONG SOLO
}

\author{
Wien Hesthi Rahayu ${ }^{1, \mathrm{a})}$ Prahastiwi Utari ${ }^{2}$ \\ ${ }^{1}$ Program Studi Magister Ilmu Komunikasi, Fakultas Ilmu Sosial dan Politik Universitas Sebelas Maret \\ ${ }^{2}$ Program Studi Magister Ilmu Komunikasi, Fakultas Ilmu Sosial dan Politik Universitas Sebelas Maret \\ ${ }^{a)}$ Hesthiwien@gmail.com
}

DOl:https://doi.org/10.18196/jkm.101003

Info artikel

Sejarah artikel:

Diterima 5 Feb 2018

Revisi 20 Mar 2018

Disetujui 20 Mar 2018

\begin{abstract}
This research is motivated by social media that brings new form of communication, so that negative impact in dissemination of information known as hoax information. This study aims to find out how the media documents that include the contents of hoax messages in the Facebook group INFO WONG SOLO. The method used is qualitative content analysis with the source of hoax information text as primary data during November 2016-February 2017. This research indicates that the Facebook group becomes one of the media of hoax information dissemination. The results obtained three major themes, namely: 1) anti-government political propaganda; 2) Muslim exclusivity; and (3) defamation of government supporters.
\end{abstract}

Keyword : elaboration, hoax, Facebook

ABSTRAK

Penelitian ini dilatarbelakangi oleh media sosial yang membawa bentuk baru dalam berkomunikasi, sehingga muncul dampak negatif dalam penyebaran informasi yang dikenal dengan informasi hoax. Tujuan dari penelitian ini untuk mengetahui bagaimana dokumen media yang mencakup isi pesan hoax yang ada di grup Facebook INFO WONG SOLO. Metode yang digunakan adalah analisis isi kualitatif dengan sumber teks informasi hoax sebagai data primer selama November 2016-Februari 2017. Penelitian ini menunjukkan bahwagrup Facebooktersebut menjadi salah satu media penyebaran informasi hoax. Hasil penelitian didapat tigatema besar yaitu: 1) propaganda politik anti pemerintah; 2) eksklusivitas umat Islam; dan (3) pencemaran nama baik terhadap pendukung pemerintah.

Kata kunci : hoax,Facebook, Analisis Isi, Kualitatif

\section{PENDAHULUAN}

Kehadiran internet tidak hanya hadir untuk sebagai kemajuan di bidang teknologi saja, akan tetapi menjadi media baru dalam menghubungkan individu ke individu lainnya dalam berkomukasi dan bertukar informasi. Seperti yang digambarkan oleh McQuail (1987) bahwa sebagai perangkat media elektronik baru yang mencakup beberapa sistem teknologi; sistem transmisi (melalui kabel atau satelit), sistem miniaturisasi, sistem penyimpanan dan pencarian informasi, sistem penyajian, dan sistem pengendalian (oleh komputer).

Komunikasi kekinian adalah komunikasi yang termediasi oleh teknologi dalam berbagai bentuk jenis media baru (Darwadi, 2017).Kemudahan yang terjadi tersebut menyebabkan mudahkan jalinan akses informasi.Akibatnya, banyak terjadi penyebaran informasi palsu atau yang lebih dikenal dengan istilah berita hoax.Peredaran berita hoax dewasa ini menjadi sebuah momok hingga Pemerintah memberlakukan peraturan agar masyarakat lebih berhati-hati dalam menggunakan internet. Pemerintah Indonesia telah memperbarui UU No. 11 tahun 2008 tentang Informasi dan Transaksi Elektronik (ITE) yang diberlakukan mulai Senin, 28 November 2016. Sehingga, perilaku masyarakat di internet termasuk di media sosial mempunyai batasan.Seseorang tidak lagi dapat berkata semena-mena di media sosial.Akan tetapi hal tersebut tidak menutup kemungkinan tersebar luasnya berita-berita palsu atau berita hoax. 
Kompas Harian pada 25 November 2016 menjabarkan bahwa media sosial di Indonesia akhirakhir ini dipadati dengan berita abal-abal.Berita-berita yang kebenarannya dipertanyakan beredar secara luas di masyarakat.Pesan-pesan yang belum tentu kebenarannya tetapi telah disebarkan di berbagai kalangan dapat menimbulkan opini publik. Seperti diketahui bahwa opini publik adalah kesatuan pendapat yang muncul dari sekelompok orang yang berkumpul secara spontan, membicarakan isu yang kontroversial, mendiskusikannya dan berusaha untuk mengatasinya.Opini publik juga dapat membuat perpecahan publik.

Penyebaran informasi yang tidak benar dengan menambahkan kalimat yang tidak sesuai dengan berita asli kemudian menjadi semakin merajalela di Facebook.Fokusnya kini tidak hanya dari satu orang saja, tetapi juga kepada pemerintahan yang saat ini berlangsung.Terlebih pada fitur grup yang dihadirkan oleh Facebook.INFO WONG SOLO adalah grup yang ada di Facebook dengan status "grup publik" (dapat diakses oleh siapa saja). Secara keseluruhan, terdapat lima grup Facebook dengan nama yang sama, di antaranya INFO WONG SOLO, INFO WONG SOLO (IWS), Info Wong Solo (grup tertutup), Info Wong Solo (IWS), dan info wong solo. Pada dasarnya kelima grup tersebut dibuat dengan bertujuan untuk saling memberikan informasi kepada sesama warga atau masyarakat yang tinggal di lingkup Solo Raya (Surakarta, Sukoharjo, Boyolali, Karanganyar, Sragen, Wonogiri).Dari kelima grup tersebut, INFO WONG SOLO merupakan grup yang jumlah anggotanya paling banyak yaitu sebesar 757.316 dan terus bertambah.

Alih-alih sebagai pusat pencarian informasi dan saling berkomunikasi, grup tersebut cenderung berisi tentang berita-berita hoax yang disebarkan oleh anggotanya. Sumber berita yang disebarkan pun tidak kredibel bahkan tidak pernah terdengar sebelumnya sebagai media massa Indonesia. Pesanpesan yang muncul atau kalimat di berita mengarah pada ujaran kebencian yang sumbernya kurang dapat dipertanggungjawabkan.

\section{Pesan Hoax sebagai Kepalsuan Informasi}

Hoax diartikan sebagai trik, lelucon, tipuan, yang lebih merujuk pada publisitas palsu.Maka dari itu dalam penelitian ini dipilih istilah informasi hoax.Pemilihan ini didasarkan pada pengertian dasar kata hoax itu sendiri (tipuan), dan bentuknya yang berupa informasi atau pesan ketika disebarkan (sebagai objek) di Facebook.

Harley (2008) menjabarkan beberapa hal yang harus diperhatikan dalam mengenali informasi atau pesan hoax, di antaranya:

1. Karakteristik pesan hoax pertama yaitu dengan adanya pesan berantai seperti model kalimat "Sebarkan ke orang lain atau beberapa orang, jika tidak maka kejadian tidak menyenangkan akan terjadi".

2. Kedua yaitu pesan atau informasi hoax tidak mempunyai tanggal kejadian atau data yang realistis serta tidak terverifikasi, contohnya hanya dengan menyebutkan "kemarin" atau "dikeluarkan oleh", pernyataan tersebut tidak memberikan kejelasan.

3. Hampir sama dengan karakteristik yang kedua, pesan hoax tidak memiliki tanggal kadaluarsa, meskipun adanya tanggal tersebut tidak memberikan bukti apa-apa.

4. Keempat yaitu tidak ada organisasi atau kelompok yang teridentifikasi atau dikutip sebagi sumber informasi atau biasanya mengutip organisasi tetapi tidak terkait dengan informasi. Sebagai contoh yaitu "Saya mendengar dari seseorang yang bekerja di Microsoft (atau perusahaan terkenal lainnya)".

Karakteristik informasi atau pesan hoaxakan terus berkembang seiring perkembangan zaman. Terdapat pula informasi atau pesan semi-hoax, yaitu informasi yang esensinya benar tetapi kegunaan dan nilainya dipertanyakan. Kebanyakan penyebaran informasi hoax berawal dari niat baik untuk memberikan perhatian atau menolong orang lain. Akan tetapi, terdapat informasi hoax yang dimaksudkan untuk kesenangan personal saat berhasil menipu orang lain.

\section{METODE PENELITIAN}

Jenis penelitian ini dengan pendekatan metode analisis isi kualitatif.Analisis isi adalah metode utama dari ilmu komunikasi. Analisis isi merupakan metode ilmiah yang digunakan untuk mempelajari dan menarik kesimpulan atas suatu fenomena dengan memanfaatkan dokumen (teks) (Eriyanto, 2011). Adapun sajian data yang ada di dalam penelitian ini adalah dengan menggunakan pendekatan deskriptif. Pendekatan deskriptif di dalam analisis isi dimaksudkan untuk menggambarkan secara detail suatu pesan, atau suatu teks tertentu. Pendekatan tersebut bukan 
bertujuan untuk menguji hipotesa, melainkan untuk menggambarkan aspek, konteks atau karakteristik dari informasi-informasi hoax yang ada di dalam Grup Facebook INFO WONG SOLO.

Tidak seperti analisis isi pada umumnya yang menggunakan kuantitatif, peneliti lebih memilih menggunakan analisis isi kualitatif.Metode tersebut dipahami dari kritikan Krippendorf terhadap Berelson mengenai analisis isi kuantitatif yang memerlukan kepercayaan bahwa pesan-pesan memiliki makna, dan kemudian membenarkan setiap analisis konvensional sebagai analisis isi. Analisis isi kuantitatif yang menitikberatkan pada yang tampak (manifest) ditentang oleh Krippendorf bahwa analisis isi juga dapat menganalisis terhadap apa yang ada di balik makna, konteks dibalik kata-kata tersebut (Rumata, 2017).

Analisis data di dalam penelitian ini adalah secara induktif.Elo dan Kyngas (2008) menjelaskan bahwa analisis isi kualitatif dapat dianalisis secara induktif maupun deduktif.Analisis isi pendekatan induktif digunakan bergerak dari spesifik menuju ke umum, jadi contoh-contoh khusus diamati dan kemudian digabungkan menjadi keseluruhan atau pernyataan umum yang lebih besar.Adapun analisis isi pendekatan deduktif adalah ketika analisis struktur diperasionalkan berdasarakan pengetahuan sebelumnya dan tujuan penelitian adalah untuk menguji teori atau hipotesa tertentu.

Data primer dari penelitian ini adalah informasi yang dibagikan pada grup Facebook INFO WONG SOLO.Teknik pengumpulan data primer dilakukan dengan menarik informasi pesan hoax yang terbit selama November 2016-Februari 2017. Waktu terebut dipilih lantaran merupakan waktu yang sarat akan masa pemilihan kepala daerah untuk beberapa wilayah di Indonesia. Sebanyak 12 informasi hoax menjadi bahan penelitian setelah dilakukan penyaringan materi pesan hoax. Penarikan data dibatasi dengan memilih informasi yang berkaitan dengan isu politik dan keagamaan.

\section{PEMBAHASAN}

Penelitian ini mengambil informasi-informasi hoax yang terdapat di dalam Grup Facebook INFO WONG SOLO. Grup tersebut bersifat terbuka, sehingga dapat dilihat oleh siapa saja (baik anggota grup atau bukan anggota grup). Grup Facebook di atas mempunyai empat orang sebagai pengurus grup yaitu akun Facebook Leny Andriany Daluas, Andika Putra, Hendri Sopyan, dan Falentino E Laksana Putra.Keempat pengurus grup tersebut bertugas untuk menerima atau mengeluarkan akun-akun Facebook yang ingin bergabung dalam grup INFO WONG SOLO.

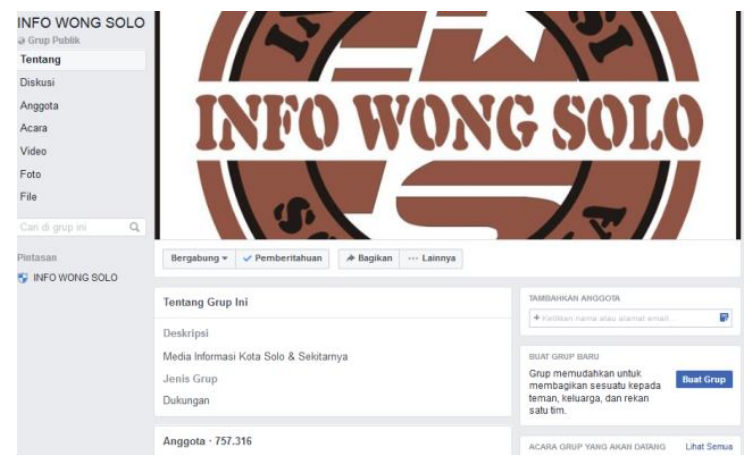

Gambar 1.Tampilan Grup Facebook INFO WONG SOLO

Hubungan dengan pesan hoax yang banyak terdapat di grup tersebut tidak berasal dari keempat akun Facebook yang bertugas sebagai pengurus atau administrator grup.Hal itu dikarenakan tampilan kolom diskusi memuat unggahan yang dapat diterima dari anggota grup.Dalam hal ini anggota grup dapat membagikan informasi berupa tulisan, gambar, video, maupun tautan (link) ke dalam grup tanpa persetujuan administrator.Unggahan-unggahan tersebut yang kemudian digunakan peneliti sebagai data penelitian.

Pemilihan data dilakukan untuk memilih informasi yang relevan dengan yang tidak. Pemilihan data dilakukan dengan mengelompokkan informasi-informasi berdasarkan bentuk informasi, yaitu: tulisan, gambar, teks dan gambar. Pemilihan dalam tahap ini dilakukan dengan membaca seluruh informasi kemudian memasukkan dalam kategori-kategori tersebut. 
Tabel 1. Tabel Definisi Kategori Bentuk Informasi

\begin{tabular}{|c|c|c|c|}
\hline No & Kelompok & Definisi & Contoh \\
\hline 1 & Tulisan & 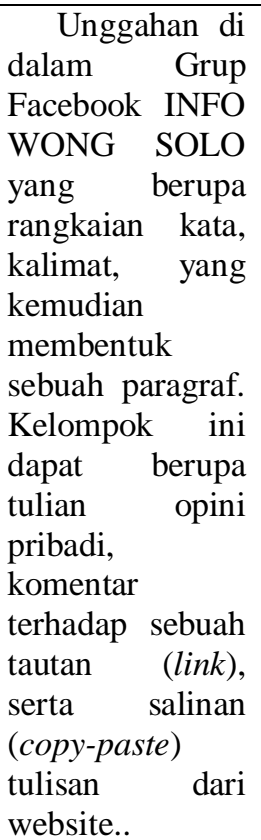 & 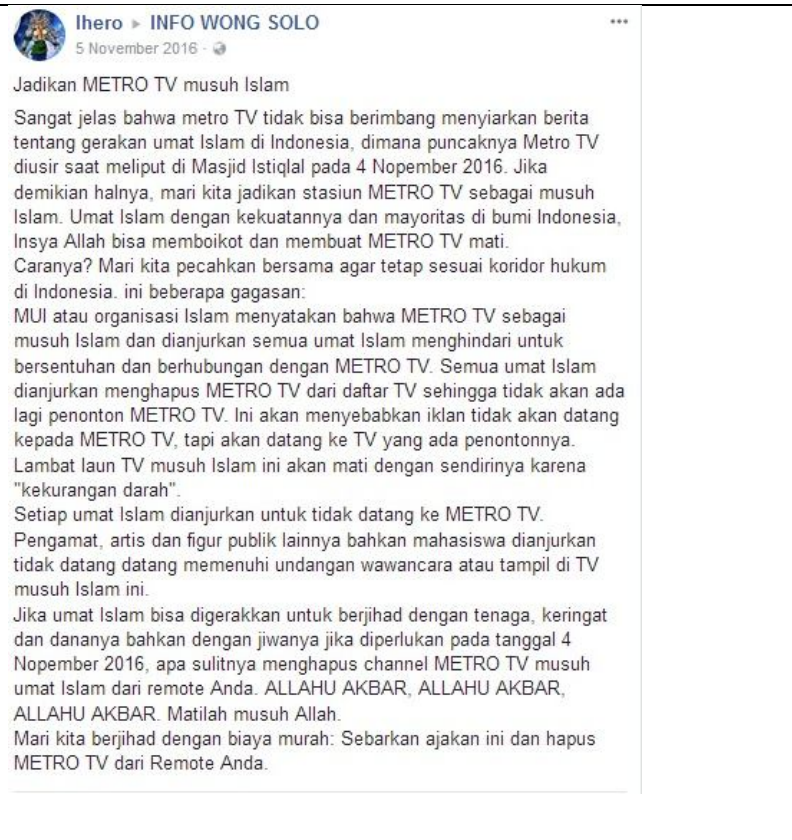 \\
\hline 2 & Gambar & \begin{tabular}{lr}
\multicolumn{2}{c}{ Unggahan di } \\
dalam & Grup \\
Facebook & INFO \\
WONG & SOLO \\
yang berfokus \\
pada bentuk \\
gambar. Dalam \\
hal ini gambar \\
dapat diartikan \\
sebagai foto \\
seseorang, \\
gambar ilustrasi, \\
atau juga dapat \\
berupa foto yang \\
berisi tulisan.
\end{tabular} & $\begin{array}{l}\text { Ajaran FPI Melahirkan Manusia yang Kurang Ajar dan } \\
\text { Arogan, video } \\
\text { Munarman saat debat dan menyiram air Teh kepada Dosen UI, Prof. Thamrin } \\
\text { Tomagola Apakah masih banyak yang ingat, Juru Bicara Front Pem... } \\
\text { NAHIMUNKARNEWS.com }\end{array}$ \\
\hline
\end{tabular}




\begin{tabular}{|c|c|c|}
\hline $\begin{array}{c}\text { Tulisan } \\
\text { dan gambar }\end{array}$ & \begin{tabular}{lr}
\multicolumn{2}{c}{ Gabungan } \\
dari tulisan dan \\
gambar yang \\
muncul sebagai \\
unggahan \\
dalam di \\
Facebook \\
WONG \\
WONO \\
INOLO.
\end{tabular} & $\begin{array}{l}\text { Q John Trump + INFO WONG SOLO } \\
17 \text { Februari - } \\
\text { Iki ora fitnah.....bukan hoax... } \\
\text { DIm islam politik pun ada petunjukny... } \\
\text { Yg terhangat dan krusial adl kasus ahok.... } \\
\text { Setidaknya memang dim islam "muslim dilarang memilih pemimpin } \\
\text { kafir(nonmuslim).... } \\
\text { Ini ajaran islam sbg pedoman dlm memilih pemimpin....baik dlm konteks politik } \\
\text { ataupun nonpolitik... } \\
\text { Jd bukan ulama ikut berpolitik justru ulama menunaikan kewajibanny sbg ulama } \\
\text { kpd umat...terserah umat mau taat apa khianat toh pertangggungjawaban di } \\
\text { akherat itu mereka sendiri.... }\end{array}$ \\
\hline
\end{tabular}

Sumber: Data diolah peneliti

Sebanyak 12 informasi hoax yang terdapat di dalam Grup Facebook INFO WONG SOLO kemudian dikelompok-kelompokkan oleh peneliti. Informasi dengan bentuk tulisan sebanyak lima buah. Bentuk informasi hoax berupa gambar sebesar dua buah. Adapun yang berbentuk gambar dan tulisan adalah sebanyak lima buah informasi, jumlah yang sama seperti informasi hoax berbentuk tulisan.

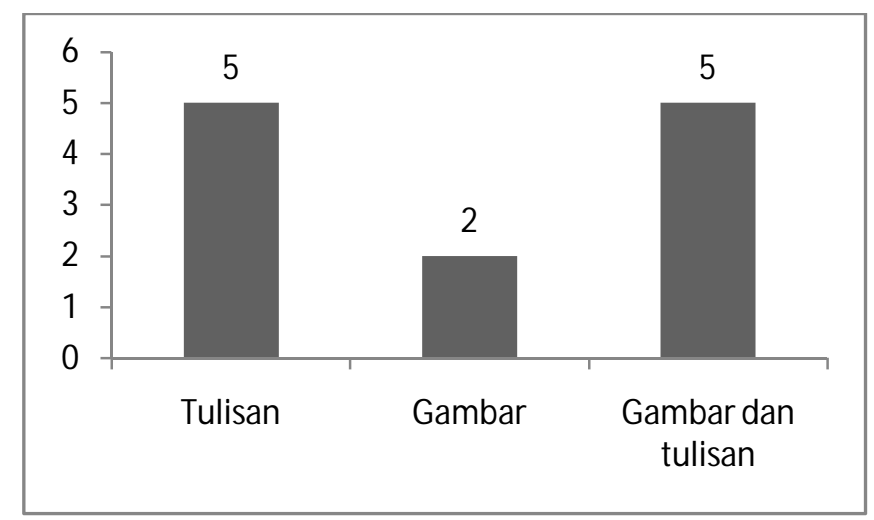

Gambar 2.Frekuensi Informasi Hoax

Grup Facebook yang menjadi media baru dalam penyebaran informasi, termasuk di dalamnya informasi hoax kemudian membawa perubahan di dalam masyarakat.Media sosial yang merupakan bentuk baru dari media membawa perubahan, yang tidak saja pada individu tetapi juga pada masyarakat.Hal tersebut yang kemudian memunculkan media sosial sebagai alat rekayasa sosial 
(Nurudin, 2013). Ditinjau dari ketiga bentuk informasi hoax yang ada pada Grup Facebook, peneliti menganalisis pada bentuk gambar dan tulisan hingga diperoleh kategori sebagai berikut: (1) opini pribadi atau pendapat murni; (2) komentar terhadap sebuah tautan (link); (3) komentar terhadap sebuah gambar; (4) salinan (copy-paste) tulisan orang lain.

Berdasarkan keempat kategori di atas, peneliti menganalisis data dengan cara mengidentifikasikan kategori-kategori tersebut dan tema-tema. Hasil dari identifikasi kategori-kategori tersebut kemudn diperoleh tiga tema besar yang muncul yaitu seperti berikut ini.

Tabel 2. Tema Analisis Pesan Hoax

\begin{tabular}{|c|c|c|c|}
\hline No & Tema & Deksripsi & Kategori \\
\hline 1. & $\begin{array}{l}\text { Propaganda politik anti } \\
\text { pemerintah }\end{array}$ & $\begin{array}{l}\text { Pesan yang berisi ajakan terang- } \\
\text { terangan untuk menjelekkan } \\
\text { pemerintah saat ini. }\end{array}$ & $\begin{array}{lr}\begin{array}{l}\text { Menentang } \\
\text { pemerintah; Ragu }\end{array} & \begin{array}{r}\text { kebijakan } \\
\text { terhadap }\end{array} \\
\text { penegakan hukum; Pesimis } \\
\text { terhadap } \\
\text { Menyebarkan isu ketidakadilan } \\
\text { terkait SARA; Menyebarkan } \\
\text { ancaman. }\end{array}$ \\
\hline 2. & Eksklusivitas umat Islam & $\begin{array}{l}\text { Pesan yang berisi himbauan } \\
\text { kepada umat Islam agar } \\
\text { memilih pemimpin yang } \\
\text { beragama Islam. }\end{array}$ & $\begin{array}{l}\text { Pendapat negatif terhadap } \\
\text { pemimpin non-muslim; } \\
\text { Ketakutan terhadap pemimpin } \\
\text { non-muslim; } \quad \text { Penghinaan } \\
\text { kepada umat selain Islam. }\end{array}$ \\
\hline 3. & $\begin{array}{ll}\text { Pencemaran } & \text { nama baik } \\
\text { terhadap } & \text { pendukung } \\
\text { pemerintah } & \end{array}$ & $\begin{array}{l}\text { Pesan yang berisi informasi } \\
\text { negatif terhadap pihak-pihak } \\
\text { yang mendukung pemerintah. }\end{array}$ & $\begin{array}{llr}\text { Labelisasi } & \text { negatif } & \text { terhadap } \\
\text { pendukung } & & \text { pemerintah; } \\
\text { Penyebaran } & \text { fakta } & \text { yang tidak } \\
\text { utuh. } & & \end{array}$ \\
\hline
\end{tabular}

Sumber: Data diolah peneliti

Beberapa temuan menghasilkan adanya topik-topik yang melatarbelakangi tersebarnya pesan hoax di Facebook. Informasi hoax yang sering muncul di internet adalah informasi dari berbagai topik demi mengelabuhi atau membohongi khalayak (audiens). Secara keseluruhan isi dari informasi hoax tidak lepas dari keterkaitannya dari proses komunikasi yang mencakup perpindahan rumor, hoax, dan mitos yang dapat memberikan efek nyata bagi kehidupan di masyarakat (Stephen, et.al, 2005).

Informasi hoax muncul dikarenakan adanya suatu tujuan.Tujuan tersebut melingkupi keinginan sebuah pihak untuk mengelabuhi masyarakat, ingin mencari pendukung atas sebuah keyakinan yang diyakini, atau ingin khalayak membenci pihak yang dibencinya juga.Hal itu kemudian muncul pada kecenderungan untuk melakukan propaganda secara terangterangan.Propaganda adalah usaha yang dilakukan komunikator dalam menyapaikan pesan kepada komunikan dengan tujuan untuk memberikan sebuah keyakinan atau doktrin. Propaganda menjadi penuh kejam dan menengangkan hanya bila pembuatnya dengan sadar dan sengaja menyebarkan apa yang mereka ketahui sebagai kebohongan, atau ketika mereka bertujuan untuk mempengaruhi yang mereka tahu bahwa tindakan mereka merugikan banyak orang (Bernays, 1928) 


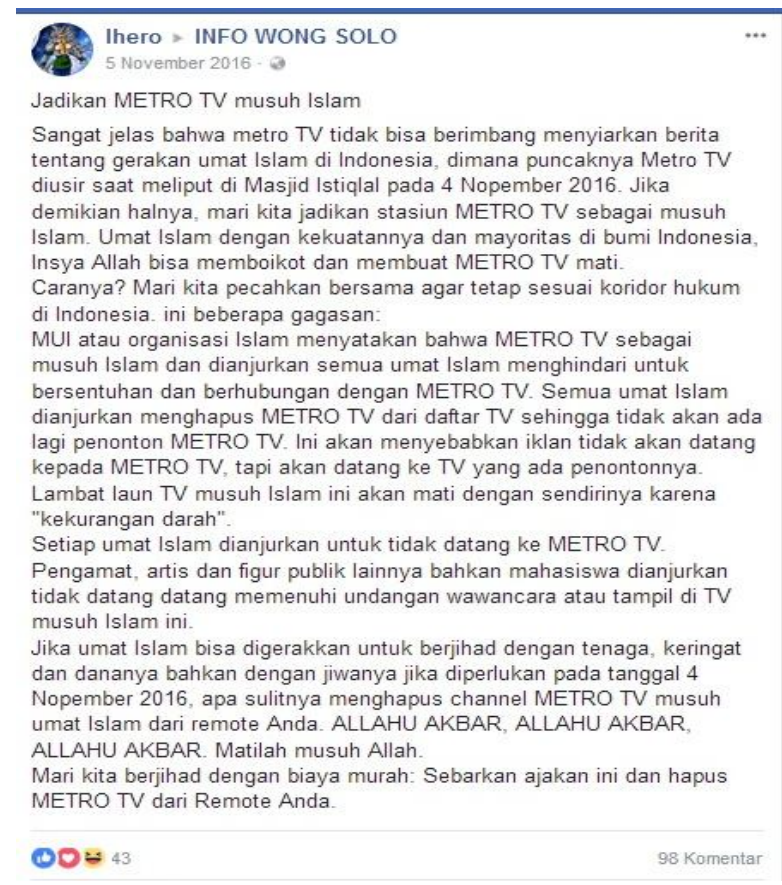

Gambar 3.Informasi Hoax dari Thero

Dalam informasi hoax yang ada di atas dapat ditemukan adanya pelabelan nama terhadap pihak yang akan ditembak sebagai objek kesalahan informasi, yang dalam hal ini adalah stasiun TV swasta di Indonesia yaitu Metro TV. pada gambar 5, juga bisa menjadi sebuah propaganda yang dilakukan dengan teknik name calling. Teknik tersebut digunakan untuk memberikan nama ejekean atau kata negatif kepada sebuah pihak untuk menciptakan pelabelan kepada khalayak (Riswandi, 2009).

Ditinjau dari kebenarannya informasi tersebut tidak memiliki bukti nyata atas kalimat-kalimat yang ditulis oleh akun Facebook bernama Ihero. Kejelasan sumber serta validitas informasi tidak dapat diketahui hanya dari bacaan tersebut (bukti yang mencantumkan nama MUI atau organisasi Islam lainnya). Hal tu menjadi satu dari jenis propaganda yang dilakukan secara terang-terang untuk menjauhi Metro TV.Sebab, jika dikaitkan dengan politik, maka Metro TV merupakan salah satu saluran TV swasta yang memiliki hubungan erat dengan Partai Politik Nasional Demokrat (Nasdem) yang diketuai oleh Surya Paloh.Pihak MUI juga tidak mengeluarkan pernyataan apapun atau berita bahwa MUI ingin menjauhi Metro TV, sehingga dapat dipastikan bahwa informasi di atas hanya sebuah opini pribadi yang dikemas secara sengaja untuk menjauhi dan membenci Metro TV.

Informasi hoax yang membahas ajakan untuk menjauhi Metro TV tersebut juga merupakan pesapesan hoax yang secara terang-terangan mencemarkan nama baik sebuah pihak. Metro TV sebagai stasiun TV yang secara spesifik berisi tayangan berita, dianggap memiliki citra buruk kepada umat Islam. Tidak hanya propaganda yang dilakukan oleh pembuat informasi hoax, tetapi juga menyinggung tentang bagaimana hal tersebut dapat dikaitkan dengan pencemaran nama baik pihak Metro TV sebagai stasiun TV yang cenderung mendukung pemerintah saat ini.

Di dalam informasi hoax pada gambar 3 tidak hanya mencakup pencemaran nama baik, tetapi juga berisi pesan-pesan yang mengaitkan dengan umat Islam sebagai kaum mayoritas di Indonesia. Pesan yang tampak adalah umat Islam dihimbau untuk tidak menonton Metro TV dengan alasan berjihad demi agama.

Adapun cara penyampaian pesan dilakukan pada tataran ajakan. Tataran ajakan merupakan satu dari empat tataran dalam cara penyampaian pesan komunikasi yang meliputi tataran isi pokok, tataran tampilan diri, tataran hubungan dan tataran ajakan (Wijayanti, 2009). Tataran ajakan yang tampak pada informasi hoax tersebut merupakan ajakan terang-terangan.Sebab awal permulaan kalimat telah menggunakan kalimat ajakan yang mengundang khalayak atau pembaca untuk menjadikan Metro TV sebagai musuh Islam. 


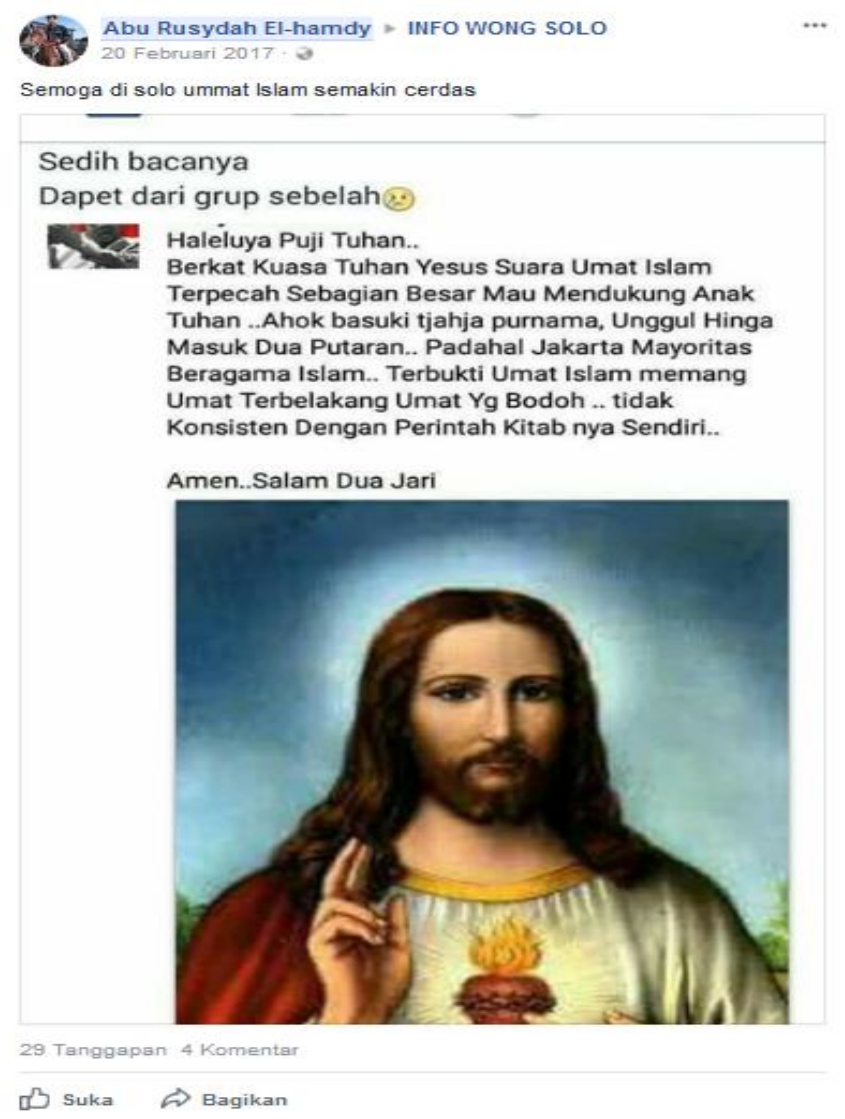

Gambar 4.Informasi Hoax dari Abu Rusydah El-hamdy

Melihat gambar di atas, maka dapat diketahui informasi hoax tersebut merupakan kegiatan propaganda. Propaganda terbuka tampak dari kalimat yang langsung terjuju jelas untuk menjelekkan umat Kristen dengan teknik transfer. Teknik transfer yaitu teknik propaganda yang dilakukan dengan cara mentransfer autoritas atau hal-hal yang memiliki nilai kehormatan ke dalam sesuatu agar khalayak dapat menerimanya (Riswandi, 2009).

Jika diperhatikan, tidak ada informasi dari sumber berita atau pesan yang menunjukkan sebuah berita.Namun, terdapat kalimat-kalimat yang menunjukkan kebohongan. Selain itu, penambahan gambar Yesus yang jari tanggannya menunjukkan salam dua jari (salam khas dari pendukung Ahok) terkesan dibuat-dibuat atau tidak nyata.

Informasi hoax pada gambar 4 juga masuk ke dalam tema besar temuan penelitian yaitu eksklusivitas umat Islam.Hal tersebut dapat dilihat dari unsur keagamaan yang dibawa sebagai topik utama di dalam informasi tersebut.Informasi tersebut bermaksud menciptakan pesan bahwa Tuhan Yesus yang sedang menulis tulisan tentang bodohnya umat Islam.Komentar dari unggahan informasi tersebut juga turut menciptakan adanya keinginan yang seolah menyatakan bahwa umat Islam tidak boleh kalah dengan non-muslim.Hal itu diperjelas dengan kalimat "Semoga di Solo umat Islam semakin cerdas". 

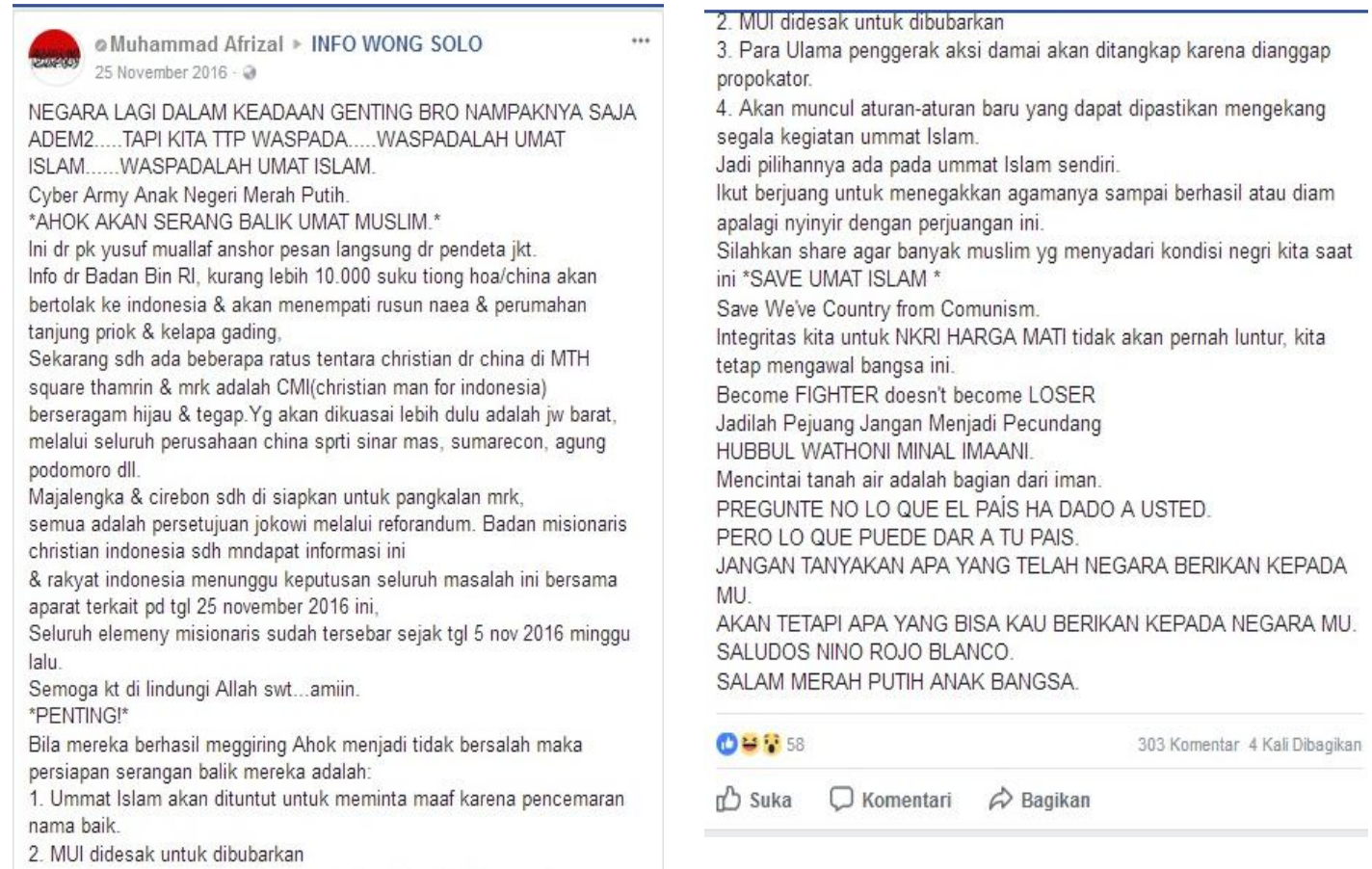

Gambar 5.Informasi Hoax dari Muhammad Afrizal

Berdasarkan informasi hoax yang tampak pada gambar 5, tertera pesan bahwa umat Islam dihimbau untuk berhati-hati serta meningkatkan kewaspadaan terhadap kondisi Indonesia saat ini.Pada informasi tersebut, dapat diketahui adanya ketakutan atau kekhawatiran yang muncul dari pembuat informasi hoax terhadap keadaan di Indonesia saat ini.Informasi yang berbentuk tulisan itu berisi tentang ajakan kepada umat Islam untuk bersikap waspada. Hal tersebut diperjelas dengan alasan banyaknya masyarakat dari China yang akan datang ke Indonesia.

“...Info dari Badan BIN RI,kurang lebih 10.000 suku thionghoa/china akan bertolak ke Indonesia \& akan menempati rusun naea \& perumahan tanjung priok \& kelapa gading. Sekarang sdh ada beberapa ratus tentara christian dr china di MTH square thamrin \& mrk adalah CMI (Christian Man for Indonesia)..."

Pernyataan di atas dapat menjadi bukti adanya informasi hoax yang tidak diketahui kejelasan dari sumber informasinya. Dari kalimat yang terbentuk, pesan di dalamnya terkandung adanya makna bahwa Indonesia sedang tidak aman lantaran banyaknya orang dari suku Thionghoa atau dari China datang ke Indonesia serta membawa misi keagamaan selain Islam, yang dalam hal ini adalat umat Kristen.Hal tersebut mengarah pada tema besar temuan peneliti bahwa pembuat pesan hoax menciptakan adanya rasa eksklusivitas dalam diri umat Islam. Rasa eksklusivitas tersebut dibentuk dengan cara menciptakan ketidaksenangan kepada umat non-muslim atau suku Thionghoa.

\section{KESIMPULAN}

Berdasarkan temuan yang diperoleh dari penelitian ini, maka dapat ditarik kesimpulan sebagai berikut:

1. Informasi hoax yang tersebar di masyarakat khususnya di media sosial khususnya Facebook lebih sering dilakukan melalui penyebaran di dalam grup facebook daripada disebarkan secara terbuka melalui akun seseorang. Intensitas dari penyebaran hoax di grup facebook lebih sering dan lebih memungkinkan untuk terbaca oleh banyak orang. 
2. Pesan-pesan yang terkandung di dalam informasi hoaxcenderung lebih merujuk pada isu-isu sensitif di sebuah negara, dalam hal ini jika Indonesia maka isu sensitifnya adalah tentang politik dan SARA. Kelompok minoritas serta mayoritas juga tidak lepas dilibatkan dalam isi pesan demi menarik kepercayaan masyarakat.

3. Pengguna media sosial khususnya Facebookdiharuskan memiliki kemampuan untuk menyaring informasi-informasi yang diterima. Penyaringan informasi perlu dilakukan pada semua pihak guna terciptanya keselarasan informasi di dalam proses komunikasi. Namun, jika seseorang kehilangan kemampuan untuk mengenali kebenaran informasi atau pesan yang diterimanya, hal itu dapat menjadi bencana komunikasi yang berbentuk hoax.

\section{DAFTAR PUSTAKA}

Bernays, Edward. 1928. Propaganda. New York: Horace Liverlight.

Darwadi. 2017. Media Baru Sebagai Informasi Budaya Global. Jurnal Komunikator. Vol.9 No. 1 : .39-48.

Elo, Satu dan Kyngas, Helvi. 2017. The Qualitative Content Analysis. Journal of Advanced and Nursing. Vol.62 No.1 (h.107-115).

Griffin, EM. 2012. A First Look At Communication Theory. McGraw Hill. E-book.

Eriyanto. 2011. Analisis Isi: Pengantar Metodologi untuk Penelitian Ilmu Komunikasi dan Ilmu-ilmu Sosial Lainnya. Jakarta: Kencana Prenada Media Group.

Harley, David. 2008. Common Hoaxes and Chain Letters, Volume 1. San Diego: ESET LCC. E-book. Diunduh dari https://www.welivesecurity.com/media_files/whitepapers/CommonHoaxes+ChainLetters\%28May2008\%29.pdf

Krippendorf, Klaus. 2004. Content Analysis: An Introduction to Its Methodology. SAGE Publication. E-book.

Kompas. 2016. Medsos Dipadati Berita Abal-abal. Kompas 25 November. 2016. Histeria di Media Sosial. Kompas 28 November.

Little John. 2011. Theories of Human Communication. US: Waveland Press.

McQuail, Denis. 1987. Teori Komunikasi Massa. Jakarta: Erlangga

Nurudin. 2013. Media Sosial Baru dan Munculnya Revolusi Proses Komunikasi. Jurnal Komunikator. Vol.5 No.2, (h.83-93).

Republika. 2016. Mulai Senin, UU ITE Revisi Resmi Berlaku. Republika 27 November. 2016. Jokowi Risaukan Cacian di Medsos. Republika 28 November.

Riswandi. 2009. Komunikasi Politik. Yogyakarta: Graha Ilmu.

Rumata, Vience Mutiara. 2017. A Qualitative Content Analysis of Twitter "\#TaxAmnesty" and “\#AmnestiPajak”. Jurnal PIKOM (Penelitian Komunikasi dan Pembangunan). Vol.18 No.1 (h.1-18).

Stephen, et.al. 2005. Proceedings of the Annual Meeting of the Association of Collegiate of Marketing Educators. (h. 85-91).

Wijayanti, Primardiana. 2009. Evaluasi Penyampaian Pesan Dalam Komunikasi. Jurnal Bahasa dan Seni. Vol.37 No.2 (h. 158-169). 